\title{
Программа совершенствования образования в сфере обороны: опыт Казахстана
}

\author{
Алан Г. Столбере
}

\section{Введение}

В 2008 году Национальный университет обороны Казахстана (КАЗ НУО) и Консорциум военных академий и исследовательских институтов по вопросам национальной безопасности инициативы «Партнерство ради мира» договорились о трехлетней программе сотрудничества. Идея программы состояла в том, чтобы ПРМ оказала поддержку КАЗ НУО в применении международных стандартов для учебных программ и методик преподавания. Программа, которая была разработана, стала известной как ПСОСО - Программа Совершенствования Образования в Сфере Обороны. Инициативы ПСОСО располагают уникальной возможностью оказывать поддержку образовательным институциям в сфере обороны стран-партнеров в области учебных программ и повышения квалификации преподавательского состава. В части развития учебных программ эта деятельность может включать создание или усовершенствование курсов или отдельных занятий, а также разработку учебных планов для новых институций образования в сфере обороны. Повышение квалификации преподавателей может включать педагогическую помощь в сфере методологии ведения занятий и технологий оценивания. Программа ПРМ оказания помощи Казахстану выполняется уже пятый год и ее реализация продолжится еще несколько лет.

\section{Как все начиналось}

В конце зимы 2007 года министерство обороны Казахстана (МО) попросило посольство США провести оценивание КАЗ НУО. Эта просьба соответствовала целям Плана действий по партнерству - строительство оборонных институтов (ПДП-СОИ), являющегося частью Индивидуального плана действий по партнерству (ИПДП), согласованного между Казахстаном и НАТО в январе 2006 года. В ответ на эту просьбу, и как элемент Программы Совершенствования Образования в Сфере Обороны, это коллегиальное оценивание было проведено КПРМ под руководством канцелярии министра обороны США (КМО) и в координации с НАТО с намерением понять, как организован процесс военного образования в КАЗ НУО. В широком смысле, область оценки включала миссию институции, организацию, учебные планы и учебные программы, состав слушателей, квалификацию преподавательского состава, библиотечные ресурсы и связь с Интернетом. Рабочая группа из шести человек провела проверку с 10 по 13 декабря 2007 года. Группа

Доктор Алан Г. Столберг является доцентом в области исследований по вопросам национальной безопасности в Военном колледже сухопутных войск США в Карлайле, штат Филадельфия. 
состояла из академических экспертов по определенным темам, напрямую связанным с потребностями принимающей образовательной институции. Перечень потребностей был составлен на основании заявления институции и связанным с НАТО ИПДП. В рабочую группу входили:

- Доктор Алан Столберг, Военный колледж сухопутных войск США

- Доктор Джек Тредденик (Канада), Центр им. Джорджа К. Маршалла

- Полковник Джордж Тигью, Военный колледж сухопутных войск США

- Полковник Синтия Коатс, отдел совместной подготовки объединенного штаба ВС США

- Подполковник Пол Райли, Центр им. Джорджа К. Маршалла

- Господин Александр Винников, Международный секретариат НАТО.

Начальник (директор) КАЗ НУО, генерал-майор Шоинбаев и его персонал были исключительно прозрачными и открытыми. Они демонстрировали дух сотрудничества и желание учиться у нас (здесь «у нас» следует понимать в широком смысле «у Запада»). Их долгосрочной целью было сбалансировать русское и китайское влияние на учебные планы военного образования в Казахстане.

КАЗ НУО является единственной в стране институцией высшего образования в сфере обороны. Он организован как двухгодичный очный курс, после окончания которого выпускники получают степень магистра в одной из трех областях: военное искусство, военная история, или технология вооружений и логистика. По аналогии с западной системой образования в сфере обороны учебные планы КАЗ НУО в основном включают образование и квалификацию, которые охватывают курс повышения квалификации (для капитанов), обучение для среднего уровня командования (Штабной колледж; для майоров) и обучение на уровне стратегического колледжа (Военный стратегический колледж; для подполковников и полковников).

Содержание учебных планов располагается где-то между уровнями Штабного колледжа и Военно-стратегического колледжа. Состав слушателей был около шестидесяти человек в выпуске, набранных из всего государственного сектора безопасности. В состав учащихся входили офицеры со званием от капитана до подполковника (от О-3 до О-5). В каждом классном отделении около 53 процентов слушателей были из министерства обороны, остальные из министерства иностранных дел, пограничной службы, министерства чрезвычайных ситуаций (или русский эквивалент EMERCON-a), президентской гвардии и некоторое число иностранных слушателей.

Первая рабочая группа ПСОСО совместно с руководством НУО рассмотрела компоненты профессионального военного образования: военное образование, практическую подготовку и доктрину. Конкретными областями обсуждения были разные учебные планы, которые распределены между шестью академическими кафедрами. На заключительной встрече анализа, начальник КАЗ НУО, генералмайор Шоинбаев, констатировал, что за последние три-пять лет учебные планы 
радикально изменились. Сейчас НУО видит опыт других стран в реформировании сектора обороны и «не хочет отставать». НУО хочет «идти по стопам ведущих стран и в некоторых областях (самому) играть ведущую роль». Директор также сказал, что в последние годы фокус военной мысли в Казахстане сместился от больших конвенциональных сражений и войн к локальным войнам и конфликтам низкой интенсивности; следовательно, «мы должны пересмотреть наши учебные планы». Затем он сказал «Вы наши стратегические партнеры - вы можете дать нам советы и предложения. Мы хотим сбалансировать учебные планы, полученные от России и Китая». В конце директор заявил, что «это была первая реальная, деловая, наполненная содержанием встреча, которая, я чувствую, содержит потенциал для настоящего сотрудничества».

Основной фокус доклада рабочей группы касался конкретных областей интенсивного сотрудничества, предпочтение которым отдавал КАЗ НУО; это была программа, основанная на потребностях, с тем, чтобы обеспечить максимальную поддержку со стороны принимающего государства и его военно-образовательной институции. До действительного визита в расположение НУО рабочая группа ПСОСО встретилась с заместителем министра обороны, чтобы еще раз убедиться, каким образом казахстанское министерство обороны видит ожидаемую помощь для НУО. Что касается КАЗ НУО, в процессе анализа было похоже, что одна из основных целей КАЗ НУО было уверить министерство, что их программы и методики достигли приемлемого соответствия международным стандартам. В направлении трансформации (или модернизации) военного образования велась работа по инициативе как министерства обороны, так и министерства образования. Главное намерение было использовать информацию этого анализа для разработки долгосрочной программы сотрудничества, которая улучшила бы военное образование в Казахстане в западном стиле.

\section{Начальная программа сотрудничества}

В случае с КАЗ НУО рекомендации, содержащиеся в начальной трехгодичной программе сотрудничества (которая осуществлялась в 2008-2011 годах), предполагали реализацию серии программ и деятельностей, направленных на оказании помощи КАЗ НУО в трансформировании в разной степени организации ведения дел в направлении подходов, которые используются в военном образовании в США и других странах НАТО. Основными областями приложения усилий в этой трансформации были развитие учебных планов, педагогические методики и дистанционное обучение. По существу, целью программы, в соответствии с целями национального ИПДП, было иметь казахский НУО с программами и методикой преподавания, которые были бы совместимы с теми, что имеют место в западных НАТО-вских институциях образования в сфере обороны.

Канцелярия министра обороны США одобрила эту программу, которая воспринималась как долгосрочный процесс, требующий сфокусированных подробных совместных обменов в тех конкретных областях, которым отдавал предпочтение КАЗ НУО. По взаимной договоренности, все конкретные программы и дея- 
тельности должны были быть направлены на решение вопросов, поставленных КАЗ НУО, и только КАЗ НУО. Ни один из рекомендованных визитов или обменов не должен был включать другие институции в или вне Казахстана, за исключением определенных многонациональных мероприятий вне страны.

В итоге, концепция многолетней программы была структурирована следующим образом:

- Год 1: Визиты и обмены для начала сотрудничества, сфокусированные на конкретных проблемах

- Год 2: Новые и последующие визиты и обмены с усовершенствованием программ по мере необходимости

- $\quad$ Год 3: Упор на продолжение начатого, с движением к самодостаточности в некоторых областях, а так же введение новых областей сотрудничества.

Долгосрочные результаты включали дополнительное время/дополнительные годы для выполнения программы уже за начальными рамками (в данном случае три года), и в конечном итоге, должны привести к тому, что в принимающей институции будет достигнут уровень, соответствующий НАТО-вским/западным стандартам образования в сфере обороны.

\section{Ежегодный анализ выполнения цеелей и корректировка планов в случае необходимости}

Начальная трехлетняя программа сотрудничества содержала взаимно договоренное условие об ежегодном возвратном визите руководителя рабочей группы КПРМ для оценки эффективности программы. Этот визит включал встречу с заместителем министра обороны для гарантирования поддержки министерства и должен был повторяться каждый год, пока осуществлялась программа. Он мог служить совместным с принимающей институцией анализом способности программы удовлетворить потребности институции как в предыдущем, так и в последующих годах. На основании наблюдений во время этих визитов в программу вносились изменения на последующие годы. В эти изменения входили подробные административные данные о предстоящих обменах, такие как точное время визитов, численность участвующего состава и конкретное содержание мероприятий.

\section{Критерии эффективности}

Были идентифицированы критерии эффективности с тем, чтобы можно было оценить, работает ли программа или необходимо внесение изменений. В случае с КАЗ НУО было решено, что эффективность будет измеряться манерой и степенью, в которой НУО активно начинает применять конкретные изменения, предлагаемые рабочей группой ПСОСО. Проведение семинара само по себе не является успехом; применение предложений семинара уже является таковым. Примерами успешных изменений являлись: 
- Педагогические мероприятия оказывают положительное влияние на преподавателей КАЗ НУО. Персонал КАЗ НУО описывает их как «жизненно важные для трансформирования традиционных» методик преподавания. Интерактивные технологии преподавания уже используются широко всеми преподавателями. Слушателям предлагают «думать», использовать «критическое мышление», «обмениваться идеями». Все это используется в тактических играх, практических занятиях и планировании операций на карте.

- Кафедра менеджмента технической эксплуатации КАЗ НУО разработала программу нового курса под наименованием «Стандарты НАТО тылового обеспечения», и КАЗ НУО установил долгосрочные отношения с румынским НУО по вопросам технической поддержки и логистики.

- В курс менеджмента основного учебного плана была включена теория лидерства и участие в ноябре 2010 года в семинаре по лидерству и этике, спонсированного Консорциумом ПРМ и проведенного с румынским НУО, что дало возможность преподавателям изложить свои собственные взгляды на эту материю.

- Уроки, касающиеся использования военно-воздушных сил, фронтовой авиации и артиллерии в Ираке и Афганистане, продемонстрированные на мероприятии в апреле 2011 года, теперь официально включены в учебные программы кафедры оперативного искусства; о них говорят, что они необходимы «чтобы не попадать в капканы старых догм».

- Лекции о западной интерпретации и преподавании международного гуманитарного права, прочитанные в апреле 2011 года, теперь включены в программу курса «Основы международного гуманитарного права».

\section{Детали программы}

В течение первых четырех лет существования программы (2008-2012) ПРМ было проведено двадцать семь мероприятий в поддержку КАЗ НУО. В их число входили мероприятия, которые включали лекции, прочитанные визитирующими экспертами студентам и преподавателям КАЗ НУО по темам, предложенным НУО, а так же семинары под руководством специалистов по тем же вопросам для слушателей КАЗ НУО. После этих мероприятий лекторы устраивали встречи с коллегами-преподавателями, на которых было возложено преподавание тех же тем. Идея этих встреч состояла в том, чтобы предоставить преподавателям КАЗ НУО необходимую для преподавания информацию (учебные цели, учебные материалы, аудио-визуальные материалы, вопросы для оценки и общий план занятий). Ко времени написания этой статьи для КАЗ НУО было проведено двадцать мероприятий, посвященных разработке программ по следующим предметам:

- Формулирование стратегии

- HATO 
- Менеджмент

- Менеджмент логистики

- Операции по поддержанию мира

- Примерная программа ПРМ

- Теория лидерства

- Экономика и бюджетирование обороны

- Семинар по лидерству

- Поддержка новой докторской программы КАЗ НУО

- Уроки Ирака и Афганистана для военно-воздушных сил/фронтовой авиации США/НАТО

- Уроки Ирака и Афганистана для артиллерии США/НАТО

- Посещение преподавателей по логистике в соответствующий департамент Школы НАТО

- Локальные войны/малые войны/локальные конфликты двадцать первого века

- $\quad$ Западный взгляд на международное гуманитарное право

- Военные и государственный контроль вооруженных сил

- Кибероборона

- Национальная военная стратегия

- Вооруженные силы и Космос

- Сетецентрические войны.

Несколько связанных с программами мероприятий было проведено под руководством или с участием других членов НАТО, и в их число входили посещение Школы логистики НАТО при НУО и оказание поддержки новой докторской программе (Канада); семинары по менеджменту технической эксплуатации и лидерству, посещение преподавателей факультета логистики в соответствующий департамент Школы НАТО (Румыния); и рабочая группа по разработке примерной программы (группа из разных стран).

Дополнительно для оказания содействия трансформации методик преподавания, применяемых в КАЗ НУО, были организованы четыре мероприятия по повышению квалификации преподавательского состава - каждое продолжительностью в несколько дней. Одно из них включало семинар, конкретно посвященный проведению практических занятий и симуляций. В каждом из этих семинаров участвовали многонациональные команды. Также два русскоговорящих сотрудника Центра им. Маршалла консультировали двух слушателей КАЗ НУО при разработке их диссертаций на соискание образовательной степени магистра. И последнее, были проведены четыре анализа для оценки эффективности и эффикасности проводимых мероприятий в течение предыдущего календарного года. В целом, 
всего двадцать семь отдельных мероприятий в поддержку КАЗ НУО были осуществлены совместно ПРМ и НАТО в течение четырехлетнего периода с октября 2008 года по ноябрь 2012 года.

\section{Что дальще с программой сотрудничества?}

И в июне 2011, и в июне 2012 года казахстанское министерство обороны подтвердило, что оно желало бы, чтобы выполнение программы сотрудничества было продолжено как минимум на три года. Преобладающая часть мероприятий, проведение которых запросил КАЗ НУО на начальных этапах, уже были не нужны. Полагая, что КАЗ НУО уже стал самостоятельным в этих областях, были запрошены другие мероприятия. Многие из заказанных программ сфокусированы на вызовах безопасности двадцать первого века, таких как вооруженные силы и Космос, кибероборона, сетецентрические подходы в военном деле, информационные элементы национальной мощи и оказание содействия для создания курса западного оперативного искусства, который отражал бы опыт США и НАТО в Ираке и Афганистане. Предполагается, что в течение последующих несколько лет будут планироваться приблизительно по девять мероприятий в год.

\section{Обобщение}

Институции профессионального военного образования в каждой стране могут иметь значительное долгосрочное влияние на будущих лидеров национальных вооруженных сил. И похоже, это как раз та модель, следовать которой сделал выбор Казахстан. Закрепление начальных уроков, усвоенных солдатами или кадетами в классе для старших сержантских званий и для офицеров среднего уровня командования, может оказывать влияние на профессиональные вооруженные силы в течение всей их карьеры, которая может длиться двадцать или тридцать лет. Это и есть основная причина, по которой личный состав вооруженных сил меняется с течением времени, и нужен работающий механизм для адаптации вооруженных сил. Если учебные планы для всех уровней обучения способствуют реализации концепции профессиональных вооруженных сил, квалифицированных в таких ключевых областях как умения для ведения боевых действий в двадцать первом веке, которые требуют инициативы и творчества, демократических и гуманитарно ориентированных военно-гражданских отношений и хорошего гражданского управления, тогда существует хорошая вероятность того, что профессиональные вооруженные силы Казахстана будут хорошим партнером как для своего национального общества, так и для других государственных и институциональных партнеров в международной системе. Если действовать правильно, действительная оперативная совместимость между вооруженными силами Казахстана и США и НАТО сможет вырасти из теории в реальную практику. 